\title{
Planctomyces maris sp. nov.: a Marine Isolate of the Planctomyces-Blastocaulis Group of Budding Bacteria
}

\author{
By JOHN BAULD* AND JAMES T. STALEY \\ Department of Microbiology and Immunology, University of Washington, \\ Seattle, Washington 98195, U.S.A.
}

(Received 3 February 1976; revised 31 May 1976)

\begin{abstract}
SUMMARY
A new marine strain of the Planctomyces-Blastocaulis group of stalked, budding bacteria was isolated: the name Planctomyces maris is proposed. Cells were spherical to ovoid, exhibited longitudinal symmetry and had a single fibrillar appendage located at one pole of mature cells. Reproduction occurred by budding at the opposite pole of the cell. The resulting daughter cell was motile by a single subpolar flagellum. The organism was an obligately aerobic, mesophilic heterotroph which utilized I 5 of $8 \mathrm{I}$ carbon sources tested for growth. It grew slowly, the shortest doubling time recorded being $\mathrm{I} 3 \mathrm{~h}$ at $30^{\circ} \mathrm{C}$. The DNA base composition was $50.5 \mathrm{~mol} \%(\mathrm{G}+\mathrm{C})$. Significant growth occurred only at salinities of $\mathrm{I} \cdot 5$ to $4.0 \%$ $(\mathrm{w} / \mathrm{v})$, and in the presence of at least $100 \mathrm{~mm}-\mathrm{NaCl}$, suggesting that the bacterium is indigenous to the marine environment.
\end{abstract}

\section{INTRODUCTION}

Gimesi (1924) reported a new colonial micro-organism which he discovered in the plankton of Lake Lágymányosi, Budapest, Hungary. His photomicrographs, though lacking in clarity, reveal that the microbe formed rosettes with numerous filiform appendages radiating from a common centre, the distal tip of each appendage terminating in a spherical structure. He believed the micro-organism was a planktonic fungus and therefore named it Planctomyces bekefii. Henrici \& Johnson (1935) found similar stalked, budding bacteria in Lake Alexander, Minnesota, U.S.A., but as they were unaware of Gimesi's previous report, they named the micro-organism Blastocaulis sphaerica.

Since these early studies numerous authors have reported the presence of the same or similar organisms in lakes. Razumov (I949) discovered a microcolonial form whose stalks were encrusted with iron and thus placed the organism in the genus Gallionella as $G$. kljasmensis. Zavarzin (I96I) subsequently recognized its similarity to Blastocaulis and renamed it $B$. kljasmensis.

Based upon her observations of lake-water samples, Wawrik (I952, I956) proposed three new species for types exhibiting iron encrustation in their stalks: Planctomyes stranskae, $P$. subulatus and $P$. ferrimorula. The legitimacy of $P$. stranskae and $P$. subulatus has been questioned by Fott \& Komárek (1960) and by Skuja (1956, 1964) because the range of morphological variation in $P$. bekefii encompasses both proposed species; and Hirsch (1972) has recommended that $P$. ferrimorula be deleted from the genus because the cells lack stalks.

Skuja (I964) has described another species, $P$. condensatus, which differs from others in

* Present address: Department of Microbiology, University of Melbourne, Parkville, Victoria 3052 , Australia. 
this group in that the cells are aggregated about a central, iron-encrusted granule. Three more species have been described by Hortobagyi (1965): $P$. gracilis with slender stalks and small cells; $P$. guttaeformis with pear-shaped cells; and $P$. crassus with stalks that are heavily encrusted with iron.

The current taxonomic status of these microbes is summarized in the description of the genus Planctomyces by Hirsch \& Skuja in Bergey's Manual of Determinative Bacteriology (1974). Though regarded as bacteria, they are placed in the genus Planctomyces because of its priority. Four species are recognized: (i) Planctomyces bekefii Gimesi (Blastocaulis sphaerica Henrici and Johnson, Planctomyces subulatus Wawrik, Planctomyces crassus Hortobagyi); (ii) Planctomyces condensatus Skuja; (iii) Planctomyces kljasmensis (Razumov) Hirsch (Gallionella kljasmensis Razumov, Blastocaulis kljasmensis Zavarzin); (iv) Planctomyces gracilis Hortobagyi. Accompanying this list of accepted species are three species incertae sedis: Planctomyces ferrimorula Wawrik; Planctomyces guttaeformis Hortobagyi, which does not have stalks; and Planctomyces stranskae Wawrik.

The extensive taxonomic and nomenclatural work on this group is in marked contrast to the paucity of information on the general biological properties of the organisms. To our knowledge not even one strain has been isolated although a monoxenic culture of a freshwater strain has been reported (Staley, 1970). Thus, we set out to isolate and characterize representatives of this group. In this paper we describe our successful attempt in obtaining a pure culture of a marine strain and discuss the biological characteristics of our isolate.

\section{METHODS}

Media. Media were prepared either with half-strength, aged, filtered $(0.45 \mu \mathrm{m})$ seawater (suffix SW) or with artificial seawater (suffix ASW) having a salinity of $3.5 \%(\mathrm{w} / \mathrm{v})(\mathrm{Kester}$ et al., I967). Unless otherwise stated, the $\mathrm{pH}$ of all media was $7 \cdot 3$ to $7 \cdot 5$. Solid media contained $\mathrm{I} \cdot 5 \%$ (w/v) Difco Bacto-agar.

The following media were used: (i) $100 \mathrm{mg}$ peptone (Difco Bacto) per litre of seawater or artificial seawater (peptone-SW or peptone-ASW); (ii) $0.25 \mathrm{~g}\left(\mathrm{NH}_{4}\right)_{2} \mathrm{SO}_{4}, \mathrm{I} \cdot 0 \mathrm{~g}$ glucose, $0.07 \mathrm{~g} \mathrm{~K}_{2} \mathrm{HPO}_{4}$, and $10.0 \mathrm{ml}$ vitamin solution (Staley, I968) per litre of seawater or artificial seawater (glucose-SW or glucose-ASW); to prevent precipitation, the $\mathrm{K}_{2} \mathrm{HPO}_{4}$ was autoclaved separately and added aseptically to the cooled medium; and (iii) $0.15 \mathrm{~g}$ peptone, $0.15 \mathrm{~g}$ yeast extract, $0.25 \mathrm{~g}\left(\mathrm{NH}_{4}\right)_{2} \mathrm{SO}_{4}, \mathrm{I} \cdot 0 \mathrm{~g}$ glucose, and ${ }^{10} .0 \mathrm{ml}$ vitamin solution per litre of seawater or artificial seawater (medium B-SW or medium B-ASW).

Enrichment and isolation. The enrichment procedure of Houwink (I95I) was used routinely. Water samples were collected aseptically from a variety of marine environments in Oregon, Washington and British Columbia. For each enrichment, a water sample (100 $\mathrm{ml}$ ) was added to a sterile $150 \mathrm{ml}$ beaker containing $10 \mathrm{mg}$ peptone (Difco) and incubated at room temperature $\left(2 \mathrm{I}\right.$ to $\left.25^{\circ} \mathrm{C}\right)$ in the dark. After incubating for 4 to 6 weeks, enrichment cultures were diluted in sterile seawater and $0^{\circ} \mathrm{I} \mathrm{ml}$ from each dilution was spread on the surface of duplicate peptone-SW plates to give final dilutions of $10^{-3}, \mathrm{IO}^{-4}$ and $1 \mathrm{I}^{-5}$. The plates were incubated at room temperature for 3 to 4 weeks. Colonies were then screened for budding, prosthecate or appendaged bacteria by phase-contrast microscopy of wet mounts. When detected, such organisms were isolated by streaking and restreaking on medium B-SW or medium B-ASW. Cultural purity was assessed both microscopically and by plating out on a number of nutrient-rich and nutrient-poor test media.

Light microscopy. Photomicrographs of cells were taken with a Zeiss Ultraphot (Oberkochen, West Germany) using a I00 $\times$ Neofluar phase objective. Slide cultures were grown on Difco Marine Agar 22 I6. 
Electron microscopy. For whole-cell studies, samples of strain 534-30 were prepared in two ways. (i) Bacteria were grown on medium B-ASW slants with the addition of $0.5 \mathrm{ml}$ liquid medium B-ASW. After 48 to $72 \mathrm{~h}$ at $25^{\circ} \mathrm{C}$ or $30^{\circ} \mathrm{C}$, bacteria were suspended in the liquid by shaking. Small droplets of this suspension were placed on Formvar-coated copper grids (200 mesh, E. F. Fullam, Schenectady, New York, U.S.A.). (ii) Bacteria were grown in screw-capped tubes containing $5 \mathrm{ml}$ liquid medium B-ASW. When turbidity was just visible, two or three stainless-steel Formvar-coated grids (200 mesh) were carefully floated on the surface of the medium. After incubation for a further $\mathrm{I} 8$ to $48 \mathrm{~h}$ the grids were removed. In both instances excess moisture was absorbed within $30 \mathrm{~s}$ with Whatman filter paper. Best results were obtained by floating grids for $\mathrm{I} \min$ on $10 \%(\mathrm{w} / \mathrm{v})$ formaldehyde and halfstrength ASW followed by a I min rinse in distilled water. Just before examination, a drop of $\mathrm{I} \%(\mathrm{w} / \mathrm{v})$ sodium phosphotungstate $\left(\mathrm{pH}_{7} \cdot 3\right)$ was placed on each grid and immediately absorbed with filter paper. Alternatively, preparations were shadowed with $80 \%$ platinum/ $20 \%$ palladium at an angle of about $10^{\circ}$.

For ultrastructural studies, exponentially growing cultures were harvested and resuspended in Kellenberger buffer (Ryter et al., 1958) with $4 \%$ (w/v) glutaraldehyde. After 2 h at $5{ }^{\circ} \mathrm{C}$, bacteria were harvested, washed twice with Kellenberger buffer, and fixed with $\mathrm{I} \%(\mathrm{w} / \mathrm{v})$ osmium tetroxide in Kellenberger buffer solution for $15 \mathrm{~h}$. Bacteria were then washed twice and mixed with $2 \%$ Difco Noble agar. Blocks $(\mathrm{I} \times \mathrm{I} \mathrm{mm})$ were cut from the agar, prestained with $0.5 \%(\mathrm{w} / \mathrm{v})$ uranyl acetate in acetone/water $(\mathrm{I}: \mathrm{I}, \mathrm{v} / \mathrm{v})$ in $\mathrm{CO}_{2}$-free atmosphere, dehydrated in acetone and embedded in a mixture of Epon 8I 2 (Ring Chemical Co., Houston, Texas, U.S.A.) and Epon 8I5 (Miller-Stephenson Chemical Co., Danbury, Connecticut, U.S.A.). Sections were cut with a diamond knife on an ultramicrotome (Zeiss) and poststained with lead citrate (Reynolds, I963) for 2 to $3 \mathrm{~min}$ before examination. All preparations were examined with a JEM-IOOB (JEOL, Tokyo, Japan) electron microscope using the lower power specimen holder. The accelerating voltage was $60 \mathrm{kV}$.

Physiological studies. All physiological tests including temperature, salinity, carbon nutrition, and vitamin requirements were carried out using glass screw-capped culture tubes containing 5 or $10 \mathrm{ml}$ medium, and incubated statically in the dark. Increased aeration was provided by shaking vigorously once every $\mathrm{I}$ to 2 days. This also helped to prevent the cells from becoming attached to the walls of the culture tubes. All inocula were examined for purity by phase-contrast microscopy. Motile swarmer cells were visible in exponentialphase cultures. Growth yields were determined turbidimetrically at $560 \mathrm{~nm}$ using a Spectronic 20 colorimeter (Bausch and Lomb, Rochester, New York, U.S.A.). The temperature range and optimum for both growth yield and growth rate were determined in medium B-SW ( $5 \mathrm{ml}$ per tube). Inoculated tubes were incubated in a thermal-gradient incubator (Matches \& Liston, I973) with a linear temperature gradient from $\mathrm{x} \cdot 0$ to $40 \cdot 0{ }^{\circ} \mathrm{C}$ (i.e. about $\mathrm{I} \cdot 3{ }^{\circ} \mathrm{C}$ per tube). Tubes were incubated for 14 days and growth was followed by direct turbidity measurements.

When determining tolerance to salinity, the inoculum was prepared by washing bacteria from slants and diluting the suspension until turbidity was just visible. One drop (about $0.03 \mathrm{ml}$ ) of this suspension was added to each tube, and then incubated at $30{ }^{\circ} \mathrm{C}$ for 9 days.

The specific growth requirement for $\mathrm{NaCl}$ was tested in medium B-ASW, with $\mathrm{NaCl}$ omitted from ASW. Two series of culture tubes were prepared with $\mathrm{NaCl}$ at $0,50,100, \mathrm{I}_{50}$, $200,250,300$ and $330 \mathrm{~mm}$. In one series normal salinity was compensated for by adding $\mathrm{KCl}$ in appropriate molar amounts, whereas in the other series the salinity varied according to the amount of $\mathrm{NaCl}$ added (MacLeod, I968; Reichelt \& Baumann, 1974). The background $\mathrm{Na}^{+}$concentration in the initial tube, $3.5 \mathrm{~mm}$, was determined by atomic absorption spectro- 
scopy. Cultures were shaken at $30{ }^{\circ} \mathrm{C}$ for 5 days before the turbidity was determined on a Beckman DU-2 spectrophotometer at $600 \mathrm{~nm}$.

Medium B-ASW without glucose was used as the basal medium for carbon nutrition studies. Carbon sources were added to give a concentration of $0.1 \%(w / v)$. Stock solutions were sterilized by autoclaving at I I $9{ }^{\circ} \mathrm{C}$ for Io min. Ethanol and methanol solutions were sterilized by filtration. The inoculum was prepared as for salinity studies except that bacteria were washed from slants and suspended in basal medium. Inoculated tubes were incubated at $30{ }^{\circ} \mathrm{C}$ for $\mathrm{I} 4$ days, and then their turbidities were determined using inoculated basal medium as the blank. Carbon source utilization was recorded as positive if the turbidity at $550 \mathrm{~nm}$ was 0.02 extinction units or greater (inoculated basal medium had no turbidity). All cultures scored as positive were checked for purity by phase-contrast microscopy.

Doubling times on medium B-SW and medium B-ASW were determined turbidimetrically either as above or using a Klett-Summerson colorimeter with a no. 54 green filter. Cultures were incubated in $250 \mathrm{ml}$ DeLong side-arm flasks $(50 \mathrm{ml}$ medium) fitted with Morton closures, in a reciprocally shaking water bath at $30^{\circ} \mathrm{C}$.

Requirements for vitamins were tested by omitting vitamins from glucose-ASW and comparing growth with that in a control tube after three serial transfers. Anaerobic growth was tested in an anaerobe jar (BBL) using medium B-ASW alone or with separate additions of potential electron acceptors (these included $\mathrm{Na}_{2} \mathrm{SO}_{4}, \mathrm{Na}_{2} \mathrm{CO}_{3}$ and $\mathrm{NaNO}_{3}$ ), each at a final concentration of $0.1 \%(\mathrm{w} / \mathrm{v})$.

DNA base composition was determined by the $\mathrm{CsCl}$ density-gradient technique (Schildkraut, Marmur \& Doty, 1962).

Cultures of strain 534-30 are grown on medium B-ASW slants at $25{ }^{\circ} \mathrm{C}$. They are maintained at 6 to $8{ }^{\circ} \mathrm{C}$ and transferred at intervals of 2 months: very slow growth occurs at these temperatures.

\section{RESULTS}

A bacterium designated as 534-30 was isolated from seawater collected at Deception Pass in Puget Sound, Washington, U.S.A.

\section{Morphology}

The appendage of the bacterium was not evident when wet mounts of cultures were examined using phase-contrast microscopy. However, an appendage was readily discernible on many cells examined with the electron microscope (Fig. I). On the larger, typically ovoid cells the appendages were in a polar position. They varied in length, some being as long as $5 \mu \mathrm{m}$ with a diameter of 0.05 to $0 . \mathrm{I} \mu \mathrm{m}$. Each appendage comprised several parallel fibrils running its entire length (Fig. 2). The electron micrographs indicate the appendage was not bound by any of the cell envelope layers and is therefore not a prostheca, but a stalk. The stalk was occasionally bent back upon itself and the fibrils frequently twisted about one another (Fig. I). Numerous fine fibres emanated from the apical tip of the stalk (Fig. I). Sometimes cells were joined together at the tips of their stalks, suggesting that these fine fibres comprise a holdfast structure. Detached stalks were observed (Fig. 2) whose basal end could be distinguished by a slight widening. The fibrils of the stalk appear to originate from separate pores located in the conical basal structure that is anchored at the pole of the cell. Though they emerge separately from the basal structure, the fibrils soon join together to form the stalk. The width of the individual fibrils is about $5 \mathrm{~nm}$. In addition to the stalk there are numerous pili, 5 to $6 \mathrm{~nm}$ diam, that extend over the entire surface of the mature cells (Fig. I).

The shape of the unicellular body of the organism varied from almost spherical for buds to ovoid for mature cells. The surface of negative-stained whole cells was convoluted with 


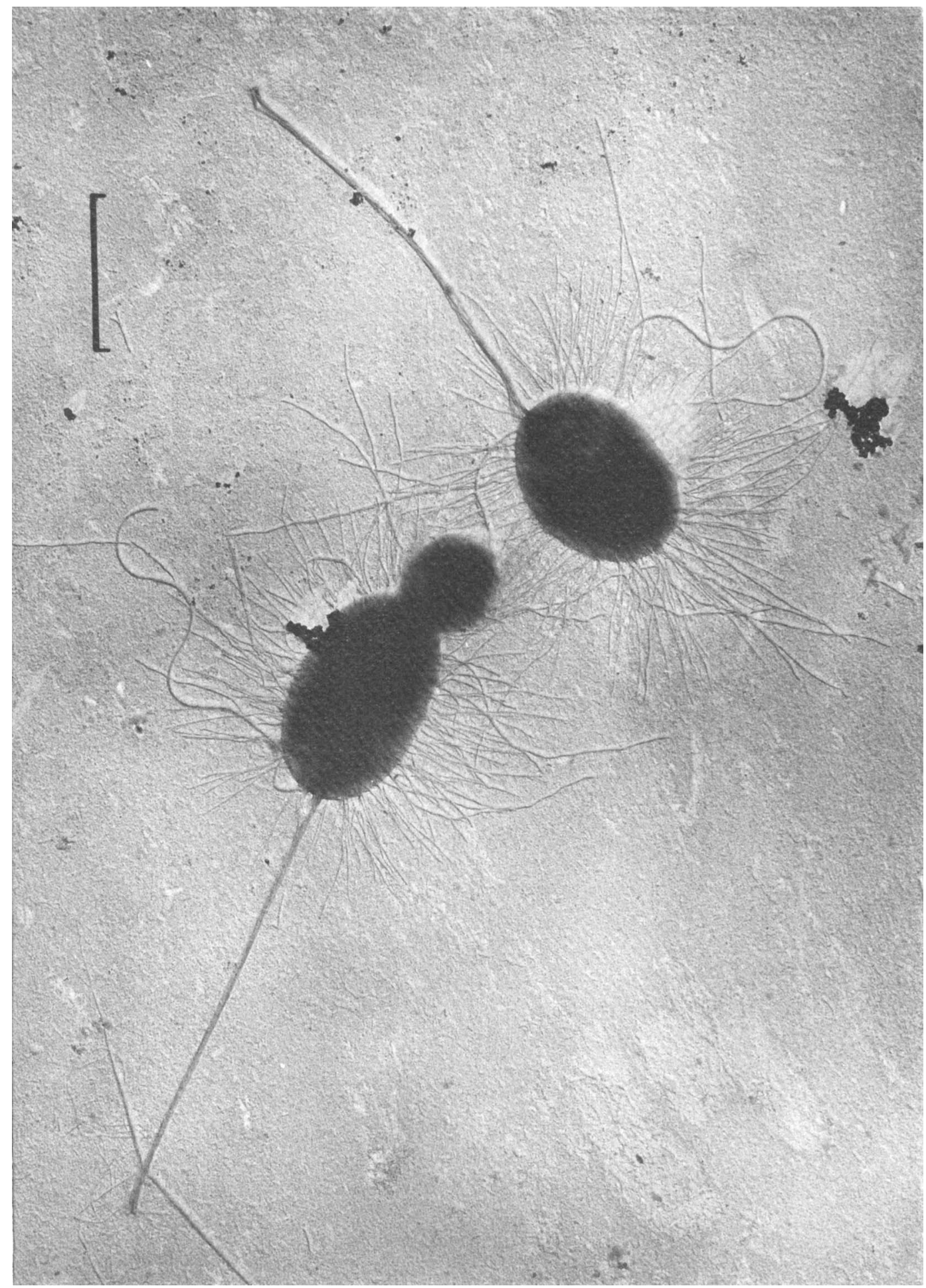

Fig. 1. A shadowed preparation showing 1 wo stalked cells, one of which is in the process of budding. Note the numerous pili. Flagella are in a subpolar position on the stalked cells. The bud also has a flagellum which is located at the pole opposite to the reproductive pole. Bar marker represents $\mathrm{I} \cdot \mathrm{O} \mu \mathrm{m}$. 


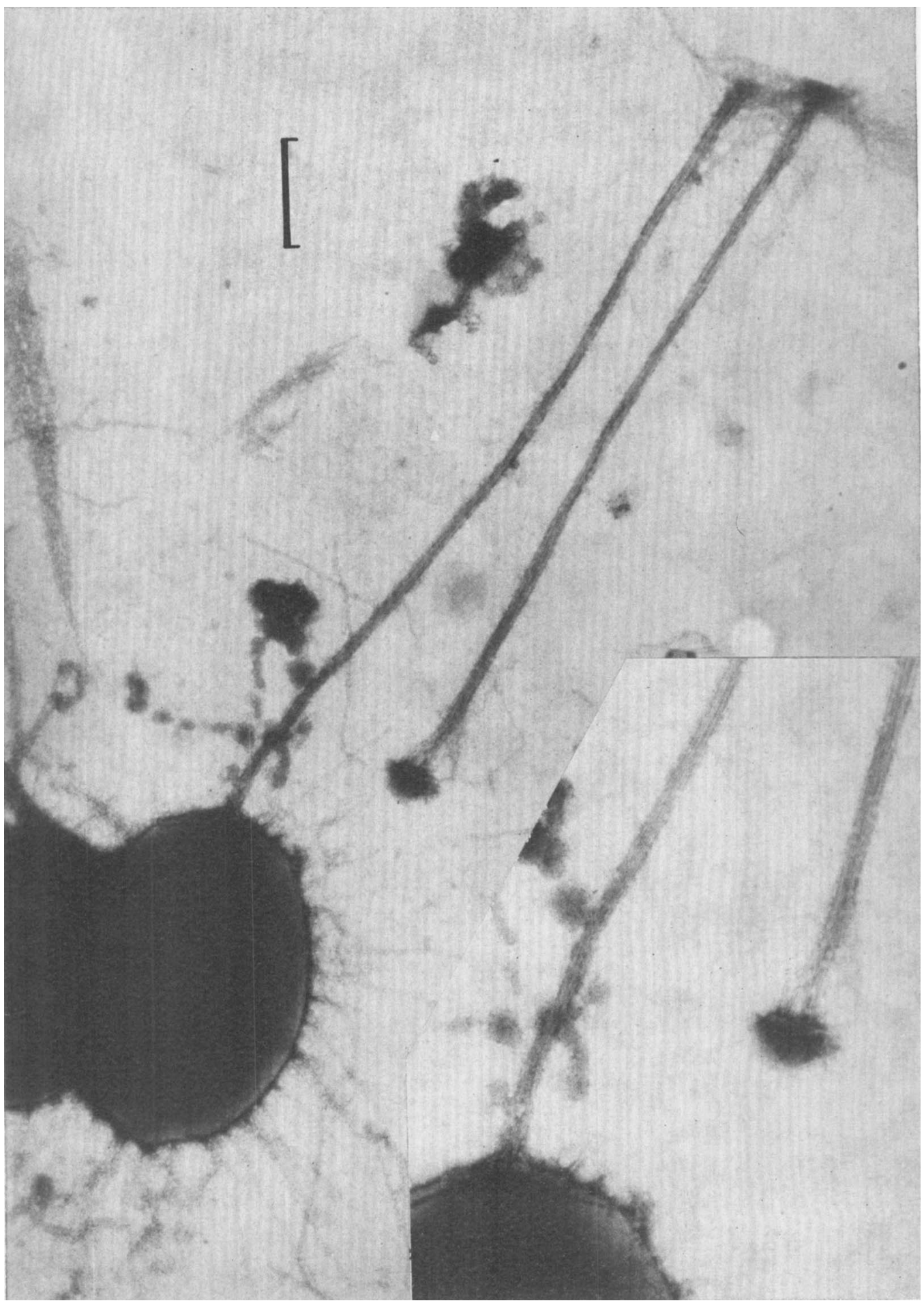

Fig. 2. Negative-stained preparation of a stalked cell and a stalk that has been separated from a cell. The lower end of the separated stalk is the basal area which was anchored in the cell. The inset shows that the stalk comprises numerous fibrils. Note that the fibrils of the stalk are separate where they leave the cell but join together a short distance from the cell. Bar marker represents $0.5 \mu \mathrm{m}$. 


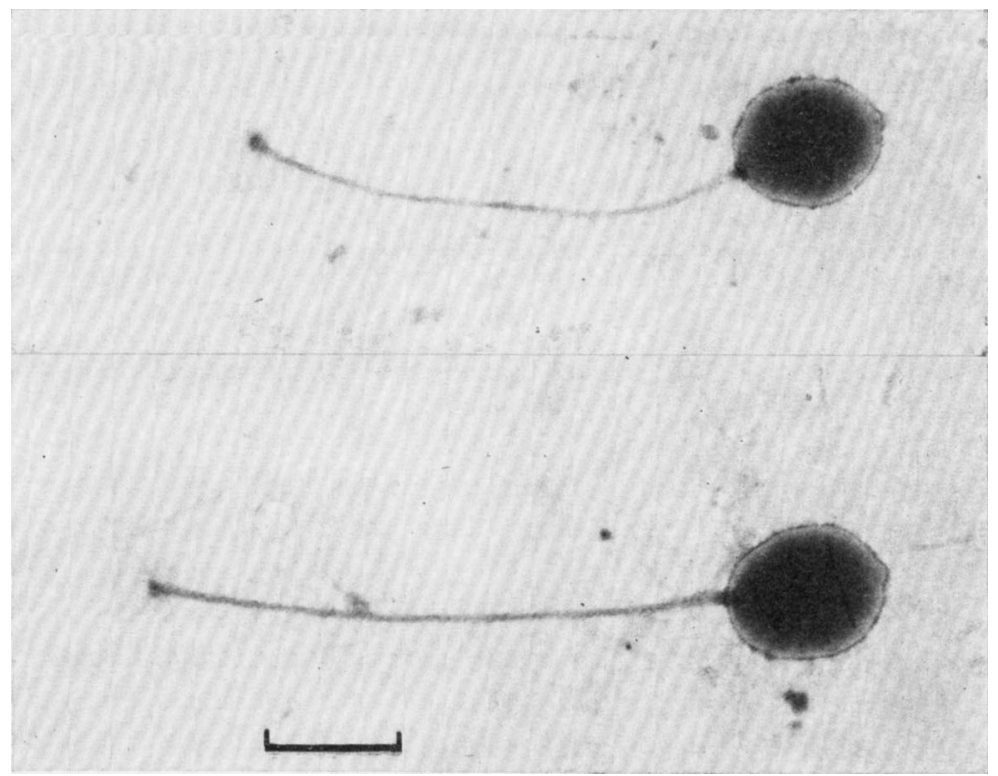

Fig. 3. Two negative-stained stalked cells showing transverse folds across the cell and the protuberance at the reproductive pole. Bar marker represents $1.0 \mu \mathrm{m}$.

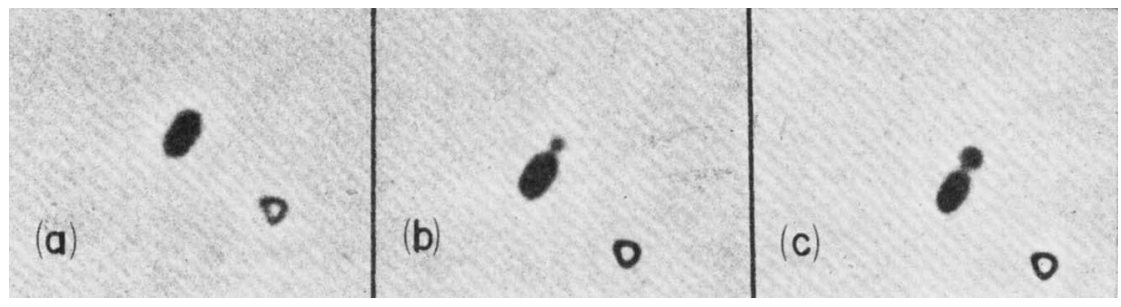

Fig. 4. A cell before bud formation ( $a$ ), and at subsequent stages of bud maturation $(b, c)$.

folds running along the transverse axis of the cell perpendicular to the stalk (Fig. 3). A small protuberance was commonly detected at the non-stalked pole of mature cells (Fig. 3) which may represent the initial stages of bud formation (see below).

Motile cells were frequently observed in growing cultures. A single flagellum was located in a subpolar position on many non-stalked as well as some stalked cells (Fig. I). On stalked cells the flagellum was commonly located immediately adjacent to the stalk. On buds the flagellum was at the pole distal to the mother cell, suggesting that the stalk arises from this same pole after flagellum formation and that the bud differentiates as a mirror image of the mother cell.

\section{Reproduction}

Examination of actively growing cultures by phase-contrast microscopy revealed many small cells, some of which were motile. The smaller cells seemed to be derived from larger cells by a budding process as electron microscopy frequently showed small cells at the nonstalked pole of larger stalked cells (Fig. I), possibly originating at the same position as the small protuberance.

When slide cultures were observed by phase-contrast microscopy (Fig. 4), a small out- 


\section{Table I. Carbon nutrition of Planctomyces maris 534-30}

Carbon sources used: glucose, galactose, mannose, rhamnose, xylose, maltose, cellobiose, melibiose, furanose, trehalose, glucuronic acid, lactic acid, $N$-acetylglucosamine, pectin, aesculin

Carbon sources not used: formate, acetate, pyruvate, propionate, succinate, fumarate, citrate, $\alpha$-ketoglutarate, malonate, benzoate, tartrate, uric acid, urea, phthalate, valerate, maleic acid, malate, caproate, glycine, DL-aspartate, L-cystine, L-cysteine-HCl, L-glutamate, L-histidine-HCl, L-glutamine, L-hydroxyproline, L-leucine, L-lysine-HCl, DL-methionine, DL-norleucine, DL-ornithine- $\mathrm{HCl}$, L-phenylalanine, L-proline, L-serine, L-arginine-HCl, L-asparagine, L-threonine, L-tryptophan, DL-tyrosine, DL-valine, DL-citrulline, creatine, creatinine, DL-aminobutyric acid, methanol, ethanol, ribose, sorbose, fucose, fructose, sucrose, lactose, melezitose, arabitol, inositol, mannitol, sorbitol, erythritol, dulcitol, adonitol, naphthol, amygdalin, alginic acid, starch, indole, inulin

growth was seen to arise on the surface of a larger cell which enlarged as growth proceeded and eventually separated from the mother cell. This process is indicative of budding.

\section{Fine structure}

Observations on thin sections of the organism confirm that it is a prokaryote in that there is no nuclear membrane or evidence of intracytoplasmic organelles. The wall structure is trilaminate, suggesting a Gram-negative bacterium. The organism stains as a Gram-negative bacterium.

\section{Nutrition and physiology}

The organism is an obligate aerobe and will not grow anaerobically with or without the addition of potential electron acceptors. It is a chemoheterotroph growing on defined medium with glucose and ammonia as sole carbon and nitrogen sources, respectively. Besides glucose, a number of other sugars and carbon sources are utilized for growth(Table I). Vitamins are not required.

The salinity range for growth as determined by maximum yield was $I^{\cdot} 5$ to $4.0 \%(\mathrm{w} / \mathrm{v})$ with the optimum at $3.5 \%$. The organism did not grow when $\mathrm{NaCl}$ was omitted from medium B-ASW even when normal salinity was compensated for by the addition of $\mathrm{KCl}$. Appreciable growth occurred in the presence of $100 \mathrm{~mm}-\mathrm{NaCl}$ plus $200 \mathrm{mM}-\mathrm{KCl}$ or of $150 \mathrm{mM}-\mathrm{NaCl}$ without $\mathrm{KCl}$. The maximum yield was attained using $250 \mathrm{~mm}-\mathrm{NaCl}$ plus $50 \mathrm{~mm}-\mathrm{KCl}$ or $300 \mathrm{mM}-\mathrm{NaCl}$ without $\mathrm{KCl}$.

The optimum temperature for growth was 30 to $33{ }^{\circ} \mathrm{C}$. No growth occurred above $37 \cdot 5{ }^{\circ} \mathrm{C}$ or below $6{ }^{\circ} \mathrm{C}$; thus strain $534-30$ is a mesophile. The bacterium grew relatively slowly, having a doubling time of about $24 \mathrm{~h}$ at $20^{\circ} \mathrm{C}$. The shortest generation time recorded was $13 \mathrm{~h}$ at $30^{\circ} \mathrm{C}$ on medium B-ASW. Growth was very slow in the absence of yeast extract and peptone (i.e. in glucose-ASW): cells appeared normal when examined microscopically and growth occurred after two or three serial transfers in the liquid medium, but the doubling time was in excess of $100 \mathrm{~h}$.

The DNA base composition was $50.5 \mathrm{~mol} \%(\mathrm{G}+\mathrm{C})$.

\section{DISCUSSION}

Since 1924 budding bacteria of the Planctomyces-Blastocaulis group have been reported from a wide variety of freshwater habitats (see Introduction). More recently, Planctomyces spp. have been reported to be present in stored seawater and marine sediments (Hirsch \& Rheinheimer, 1968). However, in the absence of axenic cultures it has not been possible to determine the physiological and biochemical properties of this group of morphologically 
unusual prokaryotes. To our knowledge this is the first reported isolation of a representative of this group. The properties of this organism justify the current classification of the genus in Bergey's Manual of Determinative Bacteriology (1974).

Like other budding bacteria, mature cells of this organism exhibit longitudinal symmetry, but not both the longitudinal and transverse symmetry typical of unicellular bacteria which divide by binary transverse fission. Also the organism exhibits remarkable structural complexity for a unicellular bacterium. The spherical to ovoid cells have three types of bacterial appendages: flagella, pili, and a unique non-prosthecate stalk (Staley, I968). This stalk comprises a bundle of parallel fibrils anchored at the non-reproductive pole of the cell. It appears to be similar to the stalks of $P$. bekefi $i$ as seen by direct electron microscope observation of natural materials (Olah \& Hajdu, I973). The bacterium can attach to surfaces by means of a holdfast structure that is located at the apical tip of the stalk.

The probable life-cycle of the bacterium can be reconstructed from electron microscopy and slide culture studies using phase-contrast microscopy. Buds are produced at the non-stalked pole, i.e. the reproductive pole of mature stalked cells. Some or all of the buds are motile by a single subpolar flagellum. The buds separate from the mother cell and, as development proceeds, pili are elaborated and the stalk and holdfast are formed, though the relative order of these events has not been determined. When mature, the cell is capable of asexual reproduction by budding.

The organism is probably indigenous to the marine environment from which it was isolated. Optimal levels for both salinity $(3.5 \%)$ and the specific requirement for $\mathrm{Na}^{+}$ $(300 \mathrm{~mm})$ are close to those of natural seawater. The optimum sodium ion concentration is at the upper end of the range ( 70 to $300 \mathrm{~mm}$ ) reported for 3I marine strains of Gram-negative heterotrophic bacteria (Reichelt \& Baumann, I974). Strain 534-30 uses a variety of sugars, some of which would be present in the marine environment as breakdown products of algal polysaccharides. Probably the organism lives saprophytically attached either to living algae, where it utilizes excreted organic materials, or to organic detritus.

Of the budding bacteria currently recognized, this organism most closely resembles those in the genus Pasteuria (Staley, 1973): all are obligately aerobic mesophiles and have similar nutritional requirements and growth rates. Cells of strain 534-30 are piliated and, like Pasteuria ramosa, attach at one pole by means of a holdfast. In both organisms daughter cells are produced by budding from the opposite pole and are motile by single polar or subpolar flagella. However, the two bacteria are readily distinguishable from one another in that the new marine isolate has a stalk whereas Pasteuria ramosa does not. In addition, the $(\mathrm{G}+\mathrm{C})$ content of the DNA from strain 534-30 $(50.5 \mathrm{~mol} \%)$ is considerably lower than that of Pasteuria ramosa ( $57 \cdot \mathrm{I} \mathrm{mol} \%$ ).

Our organism differs substantially from other appendaged budding bacteria such as Hyphomicrobium, Rhodomicrobium, Ancalomicrobium and Stella, in that its appendage is not a prostheca but a non-cellular stalk. It clearly belongs to the Planctomyces-Blastocaulis group although it differs in some respects from the species already assigned to the genus Planctomyces. Firstly, it is the only marine isolate reported for the genus. Secondly, the diameter of the stalk at $0.1 \mu \mathrm{m}$ is considerably less than those of the described species which are 0.3 to $0.9 \mu \mathrm{m}$ (Bergey's Manual of Determinative Bacteriology, 1974). We therefore recommend redescribing the genus to accommodate this organism and propose that a new species, Planctomyces maris, be created for it. 


\section{Description of the species}

Planctomyces maris Bauld and Staley (mar'is L. gen. noun maris of the sea.)

Cells spherical to ovoid, 0.4 to $\mathrm{I} \cdot 5 \mu \mathrm{m}$ in diameter. Mature cells have a fibrillar, nonprosthecate appendage, 0.05 to $0.10 \mu \mathrm{m}$ in diameter and up to $5 \mu \mathrm{m}$ in length, extending from one pole. Division occurs by budding from the non-stalked pole of the cell. Daughter cells are motile by a single subpolar flagellum. It is Gram-negative.

The organism is of marine origin and has an absolute requirement for $\mathrm{Na}^{+}$. Significant growth occurs at salinities of $\mathrm{I} \cdot 5$ to $4.0 \%(\mathrm{w} / \mathrm{v})$. It is heterotrophic, obligately aerobic, and mesophilic. The $\mathrm{G}+\mathrm{C}$ content of the DNA is $50.5 \mathrm{~mol} \%$.

Type strain: 534-30; ATCC2920r.

Source: Neritic waters, Puget Sound, Washington, U.S.A.

Cultures have been deposited in the American Type Culture Collection (ATCC2920I) and submitted to the German Collection of Microorganisms.

This research was supported in part by National Science Foundation grant GB-30313. John Bauld was the recipient of an Australian-American Education Foundation Travel Grant (Fulbright). We thank Dr Jack R. Matches, College of Fisheries, for the use of his temperature-gradient incubator. Dr Manley Mandel kindly determined the DNA base composition. R. Bigford provided excellent technical assistance.

\section{REFERENCES}

Bergey's Manual of Determinative Bacteriology, 8th edn (i974). Edited by R. E. Buchanan and N. E. Gibbons. Baltimore: Williams and Wilkins.

Fott, B. \& Komárek, J. (1960). Das Phytoplankton der Teiche im Teschner Schlesien. Preslia 32, I I3-I4I. GIMESI, N. (I924). Hydrobiologiai tanulmányok (Hydrobiologische Studien). I. Planctomyces bekefii Gim. nov. gen. et sp. pp. I-8. Budapest, Hungary: Kiadja A Magyar Ciszterci Rend.

Henrici, A. T. \& Johnson, D. E. ( I 935). Studies of freshwater bacteria. II. Stalked bacteria, a new order of Schizomycetes. Journal of Bacteriology 30, $61-93$.

HIRSCH, P. (1972). Two identical genera of budding and stalked bacteria; Planctomyces Gimesi 1924 and Blastocaulis Henrici and Johnson 1935. International Journal of Systematic Bacteriology 22, I07-I I I.

HirSCH, P. \& RHEINHEIMER, G. (1968). Biology of budding bacteria. V. Budding bacteria in aquatic habitats: occurrence, enrichment and isolation. Archiv für Mikrobiologie 62, 289-306.

Hortobagyi, T. (1965). Neue Planctomyces-Arten. Botanikai közlemények 52, I I I-1 19.

Houwink, A. L. (195I). Caulobacter versus Bacillus spec. div. Nature, London 168, 654-655.

Kester, D. R., Duedall, I. W., Connors, D. N. \& Pytkowicz, R. M. (I967). Preparation of artificial seawater. Limnology and Oceanography 12, I 76 -1 79.

MACLEOD, R. A. (1968). On the role of inorganic ions in the physiology of marine bacteria. Advances in Microbiology of the Sea $\mathbf{1}, 95-126$.

MAtches, J. R. \& Liston, J. (1973). Temperature-gradient incubator for the growth of clostridia. Canadian Journal of Microbiology I9, I I 6I-I I 65.

OlaH, J. \& HAJdU, L. (1973). Electron microscopic morphology of Planctomyces bekefii. Archiv für Hydrobiologie 71, 27I-275.

Razumov, A. S. (1949). Gallionella kljasmensis sp. n. a bacterial component of the plankton. Mikrobiologiya (in Russian) 18, 442-446.

Reichelt, J. L. \& BAUMANN, P. (I974). Effect of sodium chloride on growth of heterotrophic marine bacteria. Archives of Microbiology 97, 329-345.

REYNolds, E. S. (I963). The use of lead citrate at high $\mathrm{pH}$ as an electron-opaque stain in electron microscopy. Journal of Cell Biology 17, 208-212.

Ryter, A., Kellenberger, E., Birch-Andersen, A. \& MaAløe, O. (1958). Étude au microscope électronique de plasmas contenant de l'acide désoxyribonucléique. I. Les nucléoides des bactéries en croissance active. Zeitschrift für Naturforschung Br3, 597-605.

Schildkraut, C. L., Marmur, J. \& Doty, P. (1962). Determination of the base composition of deoxyribonucleic acid from its buoyant density in CsCl. Journal of Molecular Biology 4, 430-443. 
SkuJA, H. (1956). Taxonomische und biologische Studien über das Phytoplankton schwedischer Binnengewässer. Nova acta Regiae Societatis scientiarum upsaliensis, series IV 16, I-404.

Skuja, H. (1964). Grundzüge der Algenflora und Algenvegetation der Fjeldgegenden um Abisko in Schwedisch-Lappland. Nova acta Regiae Societatis scientiarum upsaliensis, series IV 18, 1-339.

Staley, J. T. (1968). Prosthecomicrobium and Ancalomicrobium: new prosthecate freshwater bacteria. Journal of Bacteriology 95, $192 \mathrm{I}-1942$.

StaleY, J. T. (1970). Budding bacteria of the Pasteuria-Blastocaulis-Planctomyces group. In Abstracts of the Tenth International Congress for Microbiology, Mexico, Districto Federal, p. 6. Mexico City: Editorial Muñoz.

Staley, J. T. (1973). Budding bacteria of the Pasteuria-Blastobacter group. Canadian Journal of Microbiology I9, 609-6I4.

WAWRIK, F. (1952). Planctomyces-Studien. Sydowia 6, 443-452.

WAWRIK, F. (1956). Neue Planktonorganismen aus Waldviertler Fischteichen. I. Österreichische botanische Zeitschrift 103, 29I-299.

ZAVARZIN, G. A. (196I). Budding bacteria. Microbiology (English translation of Mikrobiologiya) 30, 77479 I. 